\section{CADASTRAL SYSTEMS WITHIN AUSTRALIA}

\section{Kate Dalrymple Ian Williamson Jude Wallace}

Department of Geomatics

The University of Melbourne

Victoria, Australia, 3010

Email: ianpw@unimelb.edu.au

URL: www.geom.unimelb.edu.au/

people/ipw.html

\section{INTRODUCTION}

Australia is a federation and operates separate cadastral systems in each state and territory. These have played a significant role in shaping Australia's development. Initially they provided registration of ownership for land settlement. Then, by providing security for land transfers, they assisted establishment of a successful and complex land market. The cadastral systems have recently evolved into comprehensive instruments for assisting economic, environmental and social decision making. This is shown in broadening land tenure arrangements, recognition of traditional Aboriginal land rights, and use of new technologies to integrate cadastral information as a foundation of spatial information systems. Future objectives involve development of communication and information technologies and applications to enhance the efficiency of land registration and transfer and support the wider roles that cadastral information plays in spatial data infrastructures (SDI).

A country profile and discussion of Australia's cadastral systems follows. The fundamental processes involved in establishing the systems and the support of the surveying industry are explained. The progressive role of the cadastre in society is described in the broader context of land management and spatial information. Emphasis is placed on recent advances in automation and processes of land titling and registration and the improvements in cadastral systems to provide information effectively and efficiently within land administration systems. This overview is just that: an overview. Further investigations are required to gain a detailed understanding of each state and territory system (see acknowledgement).

\section{Geography}

Australia is the largest island continent in the world, with a total area of over 7,600,000 sq km, lying south of the Equator between the Indian and South Pacific Oceans. The population is approximately 19.5 million, with a growth rate of about $1 \%$. The majority of the population (85\%) resides in urban areas along the east and south-eastern coastline and fertile plains.

Much of the interior of the country is flat, barren and sparsely populated. The highest point, Mt Kosciusko reaching $2,229 \mathrm{~m}$, is part of an extensive mountain range running north south along the eastern seaboard. Australia lays claim to the third largest marine jurisdiction in the world, has a coastline extending more than $36,700 \mathrm{~km}$ and has administrative responsibility for seven external territories.

\section{History, Politics and Administration}

Australia was inhabited for over 40,000 years by indigenous peoples prior to British colonisation in 1788 . However their previous occupation was disregarded as rapid establishment and settlement of colonies took place. The colony of New South Wales was established on first settlement with further colonies or separated territories forming around the country to make 8 jurisdictions in total.
Land information and especially 'spatial' information are increasingly required to contribute to decision-making in an evolving environmental and information conscious society. These demands raise the importance of the cadastre underpinning spatial data infrastructures. 
In 1901 Australia became an independent member of the British Commonwealth as a Federation of States and has remained ever since. Queen Elizabeth II of England is the formal Head of State and the constitution recognises the Governor-General as the Queen's representative. Real power is held by the elected government. The Federal or Commonwealth Government is based on a bicameral Federal Parliament headed by an elected Prime Minister, consisting of a senate which has proportional

representation among the states, and a House of

Representatives, elected by preferential voting among the people in 148 electorates. The Federal Government has powers over defence, foreign affairs, trade and commerce, taxation, customs and excise duties, pensions, immigration and postal services. Other powers are the responsibility of state and territory governments, such as health, education, state transport networks, town and planning and land administration (cadastral system and land registration).

Even though there is considerable commonality, each state and territory has significant idiosyncrasies and complexities in its law governing land and the cadastral system. Within a national momentum to privatise government activities and agencies, land administration has tended to remain a government responsibility. There are four main arguments for retaining government control over the functions of cadastral surveying and land registration. These are: systematic and accurate records of boundary definition and ownership of land are of general public interest; government guarantee of indefeasibility of title (but not boundaries) to private land; the need for systematic and accurate recording for land taxation purposes as a source of important state revenue; and, government needs to protect and administer Crown and other public land to ensure against encroachment (Dale, 1976).

\section{EVOLUTION OF LAND SETTLEMENT IN AUSTRALIA}

When settlement by European colonists began in 1788 , Australia was considered an empty and unknown continent. At the time the country was settled by indigenous aboriginal peoples who identified many territorial 'countries', each under the jurisdiction of a clan group. However, as with most colonial settlements, upon occupation all land in Australia was 'vested in the Crown'. Private land rights subsequently granted by the Crown involve owners holding the land in a tenurial relationship of freehold or leasehold tenures. This contrasts with countries where absolute land ownership is recognised. Until 1992, management of Crown land and its conversion to private ownership ignored native title; then the High Court in its landmark decision, Mabo v Queensland, held that the Crown obtained ultimate or radical title to all land in 1788 burdened by the rights and interests in land occupied by indigenous inhabitants. The Federal Government in response passed the Native Title Act 1993 to validate grants, private freehold titles and other acts of the Crown which extinguished native title, and to create a system for handling native title claims in future.
Development of the Australian cadastral system was not influenced by native title or land uses of the indigenous peoples (Prescott, 1994, Ogleby, 1993, Williamson and Hunter, 1996, Williamson and Enemark, 1996). At the time of settlement, in principle, land was to be alienated and occupied after survey. Therefore surveying activities headed by the Surveyors General were given high precedence in the colonies. These were responsible for managing alienation processes for all land in the colony vested in the Crown when it acquired sovereignty, requiring a large contingency of government surveyors. However, settlement surveys were hampered by harsh terrain, unrecognisable land, rapid settlement and a shortage of professional surveyors and rigid and technical standards (Williamson, 1984, Hallman, 1973, Barrie, 1976). This led to a sporadic approach to surveying, a lack of survey control (Williamson, 1984) and development of isolated survey systems. Isolation of surveys also occurred because geodetic control surveys were overtaken by settlement surveys as the demand for land for private ownership and lease accelerated, especially after the gold rushes of mid to late 19th century. The English derived method of survey used after settlement was inappropriate (Barrie, 1976). Consequently, achieving a successful cadastral system has been a long and arduous task.

Cadastral surveys of questionable accuracy were originally undertaken using magnetic compasses and circumferenters. These were considered more portable, cheaper and quicker in the beginning due to the rugged terrain and demand for surveys (Chappel, 1996). The limitations of compass surveying were soon realised; slowly traverse methods or polar offset measurements using theodolites and chain become the popular method of survey (Dale, 1976). Today theodolites and tapes are in use, albeit with advanced functionality. Surveyors were also reliant on astronomical observations for positioning. Today the satellite Global Positioning System (GPS) has removed the need for laborious calculations and time consuming observations to provide accurate real time positioning, and is increasingly used in cadastral surveys.

\section{Development of the Cadastral System}

For about the first seventy years of European settlement, all the states relied on the English general law and a deeds conveyancing system and its back-up of deeds registration, originally modelled on Irish deeds registration. Deeds conveyancing required each change of title to be made by a deed or other legal document such as a will and probate. Collected together, the documents formed a chain of title. The system was cumbersome and expensive (Barrie, 1976). It could not solve predictable problems caused by failure to convey title through inadvertent or deliberate falsification of a document or loss of a document. A defect in a single document in the chain of deeds could nullify the title. The only advantage of registration under this system was conferral of priority over some counter claims: it could not cure fundamental defects caused by, for example, forged or defective deeds of conveyance. Remnants of the deeds system remain in the four states: New South Wales, Victoria, Tasmania and Western Australia. 
In the mid 1850s in the colony of South Australia, Robert Torrens introduced his now famous system to simplify land transfer, which had become expensive, complicated and inefficient under the general law system (Williamson, 1984). The legal profession, which had a vested interest in maintenance of the status quo opposed its introduction and the political debate resulted in Robert Torrens becoming Premier of South Australia, which aided the passing of legislation, and development of professional non-lawyer conveyancers, called land brokers or land conveyancers. By 1874 all states of Australia had adopted the Torrens System. Each state and territory has evolved into its own local system, reflecting its needs and history.

Registration of private ownership created by alienation of Crown land run by the State Land Titles Offices was unabated and highly sought after well into the $20^{\text {th }}$ century (Williamson and Enemark, 1996). Simultaneously, systems developed for management and alienation of Crown lands, usually the responsibility of the state Surveyor General. This resulted in parallel land title and land survey systems in each state and territory, one controlling private land registration and the other managing Crown lands.

Private land subdivision activities began to flourish prior to the Second World War. Today they support sustained growth in land markets. Consequently the influence of Surveyors General around Australia waned and the influence of the Registrars of Title increased as significant parcels of freehold land were generated. Today development and subdivision of land intensifies use of private lands, as opposed to servicing the alienation of Crown land, and is encouraged.

Historically a level of competition developed between Surveyors General and Registrars of Title (Williamson, 1992). Increasingly today the separate title and survey systems for Crown and private lands are being combined into one cadastral system with the objective of forming a complete cadastral record of all land parcels in a state and territory. This has been made possible by digitisation and automation of land titles and registry systems and Crown land registries. Separate administration of private and public land systems has made integration of the two into one seamless cadastral map and title register a major task. Streamlining records through computerised cadastral systems has advanced significantly over the past decade and is greatly increasing efficiency of land dealings. Legislation is also constantly being updated to reflect technology changes and evolving systems of tenure, such as native title.

\section{AUSTRALIAN LAND MARKET}

Australia has a prosperous Western-style capitalist economy supported by a well educated population, expansive natural resources, a strong financial sector and good infrastructure. With this standard of living Australians place a high value on home ownership with about $70 \%$ of families owning their own free standing house or apartment.
Most of the population live in detached houses having a land area of about 500 to 1,000 square metres. On average, Australians sell their homes and buy or build new ones about every ten years. An increasing percentage of the population live in medium density housing (about 15\%). These are often individually owned building subdivision apartments, in multistorey buildings or small adjoined or stand-alone clustered dwellings sharing a reserved area of common property.

Government incentives to invest in real property for first homebuyers and lending policies of financial institutions are making home loans (mortgages) more accessible. Most real property is purchased by borrowing money from a bank (up to about $80 \%$ to $90 \%$ of the purchase price can be borrowed) in exchange for a mortgage. Interest rates are currently about $6.5 \%$ per annum with loans repayable usually over a maximum period of 30 years. The price of land, especially in the larger cities, has accelerated reflecting a healthy competitive market and tax advantages available for residential land owners and investors.

On average it takes about four weeks to transfer land in Australia with conveyancing fees being about AUD\$500 AUD\$1000 (AUD\$1 = USD\$0.61, April, 2003) per land transfer. Much faster transfers are possible, especially if the purchaser is not seeking bank finance to assist in the purchase. In these cases a transfer could be completed in less than a week. Government taxes, known as 'stamp duty' of up to $6 \%$ of the purchase price must also be paid. The requirement of a cadastral survey by licensed surveyors to re-establish property boundaries at the time of land transfer is normal practice in some states, notably New South Wales, although it is not compulsory. This ensures the house is built on the parcel of land described in the land transfer and title and that the building does not contravene any local government ordinances. These cadastral surveys, called Identification Surveys, cost about AUD\$600.

The land market operates almost totally within the private sector with the only exceptions being the operation of the Land Titles Offices and the oversight of cadastral surveys and licensing of surveyors by a Board of Surveyors or an equivalent body in each state. State and federal governments are also involved in alienating several thousand remnant government owned parcels each year across Australia. The major players in the land market are land owners, land developers and planners, land surveyors, conveyancers (lawyers and others), real estate agents and financial institutions.

\section{LAND ADMINISTRATION AND CADASTRAL SYSTEMS Land Administration}

As a Federation of States, Australia maintains centralized land administration offices in each jurisdiction. There is no prescribed organizational structure common to all states; land administration is a state government responsibility performed under a range of government departments such as Environment, Planning, Lands or Land Administration. 
Embedded in these departments are the State's digital cadastral map, land registry and titles office, Crown lands management office, Surveyors Board, and business units for land information and resources. Combinations of these services can be found in each state, integrated through sharing agreements. Today this is assisted by the computerisation of spatial and non-spatial information. A consortium of all states and the Commonwealth, called the PSMA Australia Ltd (Public Sector Mapping Agencies), produces national digital cadastral map products comprising about 10.2 million land parcels.

\section{Current Cadastral Systems}

The cadastral systems in Australia are historically based on registering land transactions generated by a land market. The second role of the cadastral system is to support the registration of land for legal ownership, registering the rights, restrictions and responsibilities pertaining to land through precise surveying methods regulated by government licensing. Although cadastral systems vary across the nation, the integrity of each system is consistent allowing the core spatial data set in spatial data infrastructures to play a fundamental role in broader land administration activities. Computerisation of spatial and textual data establishes the cadastre as an integral tool in many areas. These include facilitating:

- in a legal capacity, the registration of ownership of land;

- in a fiscal capacity, valuation of land sales and taxation; and

- more widely, in multipurpose functions in land management and planning for local government, emergency response, Australian Bureau of Statistics data capture, environmental risk assessment, and business planning.

Cadastral systems are basically created by surveying land parcels in the field and recording the corresponding land ownership titles in the land registry. There is generally a 1:1 relationship between these two main units, that is each land parcel is related to one land ownership entry in a folio in the land register.

The term "property" is used by local councils which maintain property records for their own planning and rating purposes. A property has one street address, but can consist of one or many, normally adjacent, parcels owned by the same landowner. In probably $90 \%$ of the cases, however, a property consists of one parcel only. While the land ownership title is of interest to the land registry, the use of the term 'property' reflects the different needs of the local councils and utilities and is not a formal entity of the cadastral system. Buildings are part of the property records and are recorded by the local councils as well.

\section{Components of Australian Cadastral systems:}

- Textual component - the land register identifies real property parcels, which includes all land parcels concentrating on those held privately in freehold ownership and identifies owners' rights, restrictions, and responsibilities, ownership, easements and mortgages.

- Spatial component - cadastral maps show tradeable land parcels graphically corresponding to the registered title with plan numbers and unique identifiers in a fully computerised system. Treatment of public land and roads varies among the jurisdictions. Cadastral maps consist of fixed and general boundaries, about $90 \%$ and $10 \%$ respectively:

- Fixed boundaries are those with legally surveyed measurements used to precisely identify most parcel boundaries determined by cadastral surveys such as a subdivision.

- General boundaries (graphical) are not survey accurate and are based on natural or artificial physical features, such as high water mark, or walls and buildings as found on building or strata subdivisions.

- Crown lands management have management and administrative responsibility for state owned lands. Details of Crown lands, including land parcels leased or licensed to the public, parks and reserves, government land and excess land, are kept less formally than land registry records.

Additional legal, valuation, local government, utilities and planning activities are involved in land administration, and are heavily reliant on the fundamentals of the cadastral system. In particular collection of local government rates, land tax and stamp duty (payable on transfer, mortgage and lease of land) relies on land parcels and are major revenue raisers for the state and territory economies.

Land titles and registry offices in each jurisdiction comprise of very large and complex organisations. They store vast amounts of paper records and now computerise almost all dealings. For example the Land Registry in Victoria has about 2.5 million land titles, 3.8 million parcels, 0.43 million plans of survey (including plans of field notes) and 14 million live supporting documents. The population of the State of Victoria is about 4.9 million persons.

\section{Land Registration}

The Torrens system is a system of title registration where the law guarantees that the person shown on the title (Figure 1) displayed in a public register is the registered proprietor. The folio of the register is conclusive evidence that the person named in the folio as the proprietor of an interest in the land is the legal owner of that interest. Interests in land can only be created, varied or changed by registration (with some exceptions). If there is an error on the register, the government may compensate for any loss incurred by the error. These standards are summarised as three fundamental principles of the Torrens system; namely the Mirror Principle, Curtain Principle and Insurance Principle. The Mirror Principle ensures that the register reflects legal interests in the land. The Curtain Principle means that once a registration occurs unregistered interests affecting the land are not enforceable against the registered owner. It is not necessary to look 
behind the title to investigate previous interests. The Insurance Principle means that the information on the register is guaranteed by the State. The Torrens system as conceived had four qualities: speed; simplicity; cheapness; and suitability to the needs of the community. It is remarkably successful despite the complexities of common law and the cadastral survey system. It offers relatively cheap conveyancing, though, like all systems which meticulously record interests in land, it is sometimes slow.

There are three components in a Torrens title. The parcel section identifies the parcel boundary, giving it a unique identifier and describing the metes and bounds (usually graphically by reference to a plan of survey). The proprietorship section identifies the owner, and the encumbrances section identifies any other interests in the parcel such as a mortgage, an easement or a restriction as to use. In the paper based system, the registered proprietor holds a duplicate of the title held by the land registry. The paper certificates (Figure 1) are being phased out as the administrations convert to computer based systems and electronic conveyancing. In Victoria new digital titles such as the one in Figure 2 are now being produced. Unlike the original certificates of title, the parcel section which often included a sketch of the parcel is not included, it is instead available as a separate document.

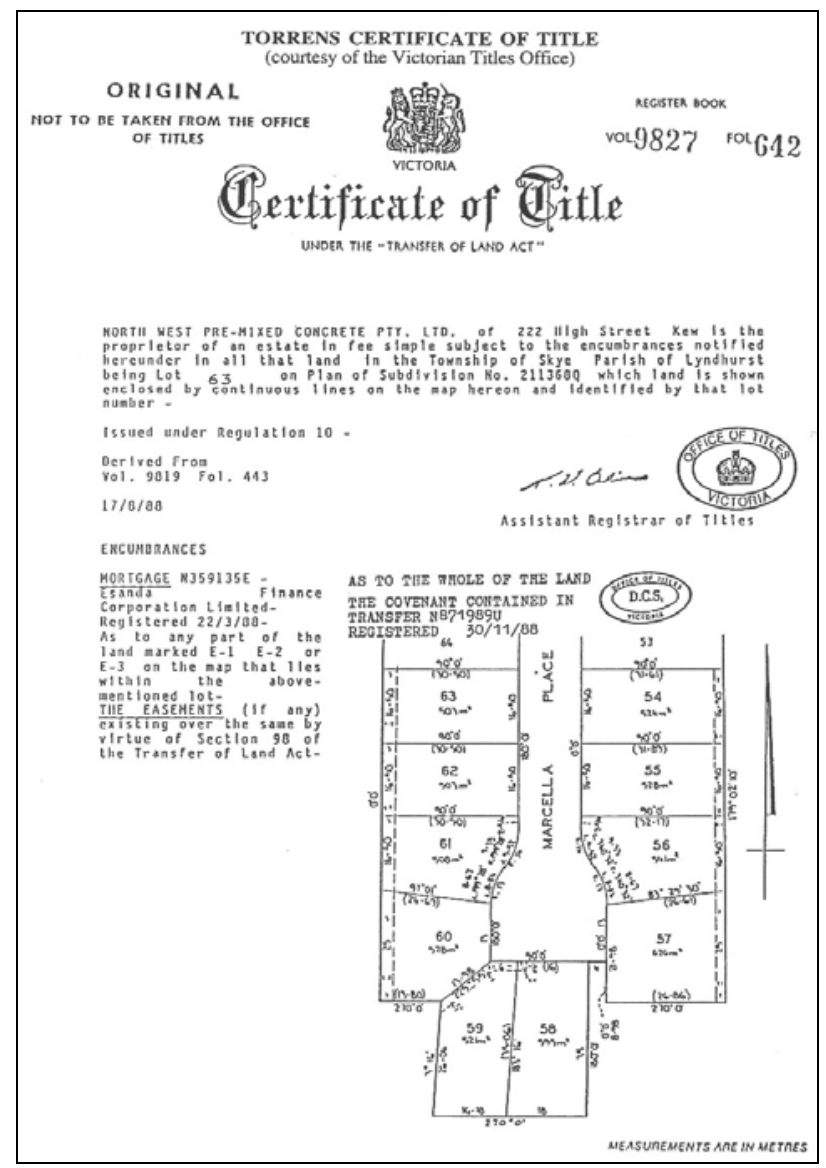

Figure 1 - Original Certificate of Title (Courtesy of the Victorian Land Registry)

Acts of Parliament support the cadastral system within each jurisdiction. The legislation controlling the Torrens system is usually called a Real Property Act or Land Transfer Act. The Torrens legislation and practices of state and territory registries differ in detail. Significant differences are in how far each system allows unregistered interests to impact a title. In case of leases, all jurisdictions allow leases exceeding three years, and some allow shorter leases to be registered. In practice however in Victoria leases are usually not registered because "interests of tenants in possession" override titles. In other states only short term leases are protected and registration of leases is common. All jurisdictions make provision for registration of easements (such as rights of drainage, rights of way or support). Victoria uses extensive registration of easements on the titles of dominant and servient land, even though its legislation protects unregistered easements anyway. In some other states registration practices and supporting legislation remove the need for slavish entry of the detail of easements on titles. Treatment of adverse possession is highly variable (Park and Williamson, 1999). Victoria (which requires the longest period of possession of 15 years) and Western Australia protect adverse possession of whole and part parcels. Other states have varying regimes, some very hard to follow, with the Australian Capital Territory (where surveying standards are strongest, and land is held typically by lease) taking the other extreme so that no title to land adverse to the registered owner can be

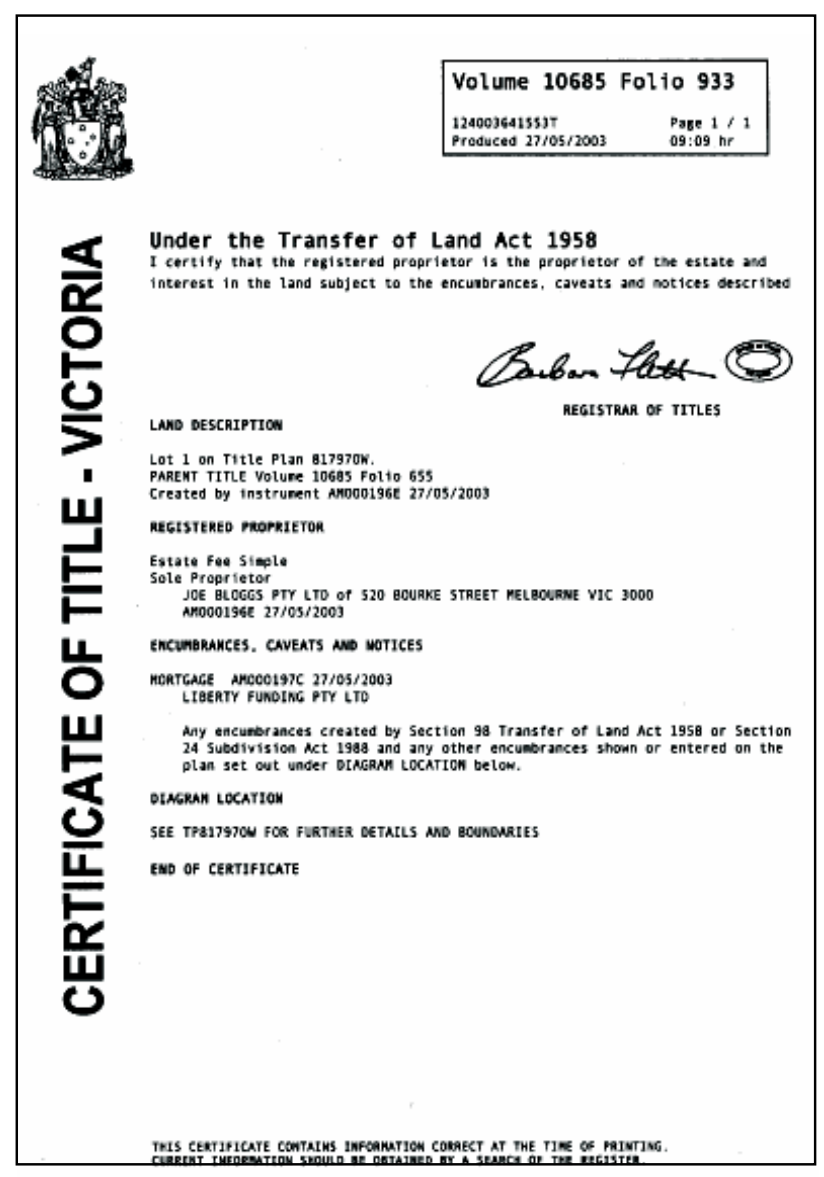

Figure 2 - Digital Title Record (Courtesy of the Victorian Land Registry)

acquired by any length of possession. The varying approaches produce what might be described as counter 
intuitive results: in Victoria surveys on sale are unusual and the purchaser "sees what he buys" with confidence, whereas in New South Wales where title by adverse possession of whole parcels is much harder to acquire and encroachments are dealt with by a special legislative scheme, surveys accompanying sales are normal.

Over the last forty years or so all states introduced building subdivision legislation to allow real property to be subdivided vertically as well as horizontally thereby permitting individual ownership of apartments. An enormous impetus to the development of medium to high density housing resulted. The legislation continues to evolve to reflect social needs and building techniques. Strata, cluster, community and retirement village titles are variations on the theme.

Other legislation provides legal infrastructure to the land market including legislation supporting the sale and mortgage of land, environmental protection, planning and local government services supporting the occupation and development of land.

\section{Cadastral Surveying}

Australia has over two centuries of expertise in cadastral surveys of parcel boundaries. Historically cadastral surveying was not part of the government state-wide cadastral mapping process. Surveys of individual land parcel boundaries are carried out to a high mathematical precision and until recently were only connected into neighbouring land parcels. Corners of parcels are typically marked with wooden pegs with reference marks usually buried adjacent to corners. These surveys are called "isolated" surveys, as in most states these are not based on coordinate systems. In fact, coordinates were not permitted to be shown on many cadastral survey plans in Australia until recently; cadastral surveys in the Australian Capital Territory are an exception in that they have always been based on a coordinate datum.

Meanwhile, the value of a coordinated system to the community is increasingly acknowledged and now most cadastral surveys require connection to a datum. In Victoria the Geocentric Datum of Australia (GDA) is the geographical coordinate datum for spatial information using a network of Permanent Survey Marks (PM), which tend to be concrete blocks or marks in concrete kerbs, and the Map Grid of Australia (MGA) is the preferred coordinate system. The normal measurement precision for urban cadastral surveys is 1 part in 4-10,000 with traverse closures of 1:8,000 (Figure 3 ). The connection of surveys to a coordinated system plays a significant role in increasing the integrity of the cadastre allowing it to better cope with the integration of additional spatial information and transferability to an Australia wide mapping system for multipurpose use.

Cadastral land surveyors use the latest technology including digital theodolites, Global Positioning Systems, "field-to-office" techniques and computerised drafting systems in undertaking cadastral surveys and preparing cadastral plans. Some states permit cadastral plans to be submitted to the Land Registry in digital form to facilitate updating of the digital cadastral mapping system. Standard cadastral procedures are regulated by Acts and Regulations in each jurisdiction.

Figure 3 - Cadastral Survey Field Notes (Courtesy of Victorian Survey Practice Handbook)

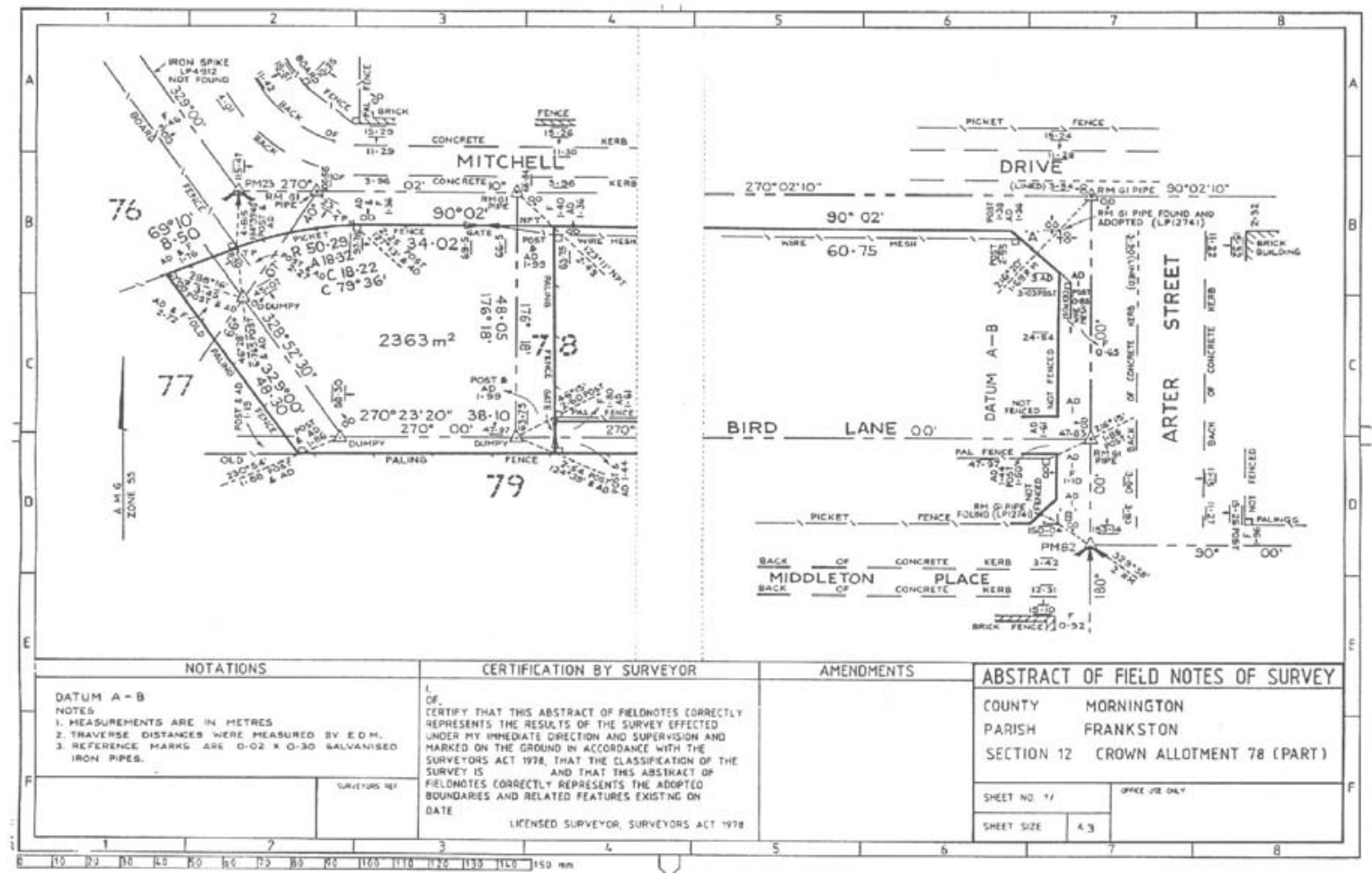


Cadastral surveying is undertaken by professional land surveyors, licensed or registered. Applicable Acts and Regulations specify the duties and responsibilities of these surveyors, establish a Board of Surveyors and set qualifications for registration. Processes such as surveying related to land transfers and subdivision currently can only be performed by a licensed/registered surveyor to ensure integrity in updating the cadastre.

The following two tables briefly outline the involvement of professionals in the land transfer and subdivision processes.

\section{Land Transfer Process}

\begin{tabular}{|l|l|}
\hline \multicolumn{1}{|c|}{ PROCEDURE } & \multicolumn{1}{|c|}{ WHO } \\
\hline $\begin{array}{l}\text { Prepare Statement } \text { on details of } \\
\text { property, title, zoning, rates, } \\
\text { restrictions, services information } \\
\text { etc. }\end{array}$ & Vendor or \\
\hline
\end{tabular}

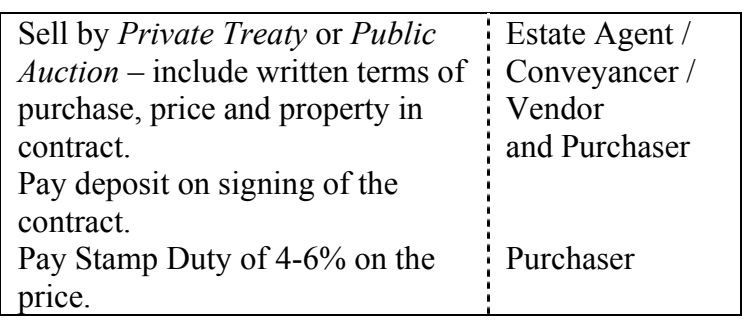

\begin{tabular}{|l|l|}
\hline $\begin{array}{l}\text { Search Title-verify guaranteed } \\
\text { record at land registry }\end{array}$ & Purchaser or \\
Undertake Identification Survey & Conveyancer \\
in some states & Surveyor \\
\hline $\begin{array}{l}\text { Wait Contract Period -period } \\
\text { between vendor selling and } \\
\text { purchaser gaining possession, } \\
\text { organise finances and payment to } \\
\text { vendor }\end{array}$ & Cendor / \\
\hline
\end{tabular}

\begin{tabular}{|l|l|}
\hline Prepare Transfer of Land Form & Conveyancer / \\
Pay Stamp duty & purchaser / \\
Sign and lodge land transfer form. & bank \\
A copy of the new title is given to & \\
the purchaser or, bank (if & \\
mortgaged) & \\
\hline
\end{tabular}

\begin{tabular}{|c|c|}
\hline $\begin{array}{l}\text { Notify local council, water } \\
\text { authority, body corporate (of } \\
\text { building subdivision) and Land } \\
\text { Tax Office of the change of } \\
\text { ownership }\end{array}$ & $\begin{array}{l}\text { Purchaser / } \\
\text { Conveyancer }\end{array}$ \\
\hline
\end{tabular}

\section{Subdivision of Land Process}

\begin{tabular}{|l|l|}
\hline \multicolumn{1}{|c|}{ PROCEDURE } & \multicolumn{1}{c|}{ WHO } \\
\hline $\begin{array}{l}\text { Purchase/own a parcel of } \\
\text { land and the certificate of } \\
\text { title }\end{array}$ & Land owner \\
\hline
\end{tabular}

\begin{tabular}{|c|c|}
\hline $\begin{array}{l}\text { Prepare subdivision design } \\
\text { - refer to council and state } \\
\text { regulations }\end{array}$ & Surveyor/Planner \\
\hline
\end{tabular}

\begin{tabular}{|l|l|}
\hline $\begin{array}{l}\text { Apply for subdivision } \\
\text { permit-submit plan }\end{array}$ & $\begin{array}{l}\text { Surveyor/Planner } \\
\text { Referral Authorities }\end{array}$ \\
\hline $\begin{array}{l}\text { Discuss Subdivision } \\
\text { Design- review by } \\
\text { independent authorities }\end{array}$ & $\begin{array}{l}\text { Client, Council, } \\
\text { Referral Authorities } \\
\text { (Water, Sewerage, Gas, } \\
\text { Electricity and } \\
\text { Telecommunications) }\end{array}$ \\
\hline $\begin{array}{l}\text { Conduct Final survey - re- } \\
\text { establish the boundary, } \\
\text { connect to AMG }\end{array}$ & Licensed Surveyor \\
\hline $\begin{array}{l}\text { Full plan of subdivision- }- \\
\text { establish new individual } \\
\text { parcels }\end{array}$ & Client submission \\
\hline Issue Titles & Louncil approval \\
\hline
\end{tabular}

\section{CADASTRAL MAPPING}

From 1980 to 2000, states and territories moved to establish complete cadastral maps as a fundamental framework supporting spatial information for land management, land administration and local government administration. The typical technique in establishing these cadastral maps involves fitting all the isolated cadastral survey plans together on to a topographic base map using fence lines, road boundaries, physical features, etc as control, utilising a rubber sheeting approach, particularly in rural areas. The integration of these components facilitates the process to generate unique parcel identifiers for every land parcel to enable better identification and cross referencing. As such the overall cadastral mapping system was developed from the "part to the whole" as distinct from the normal surveying practice of going from the "whole to the part" (Barrie, 1976). This reflects the historical development of cadastral surveys, in terms of the alienation and settlement based land transfer and registration requirements.

The necessity for coordination of national surveys for mapping was realised during the first world war, in the early 1900s (Barrie, 1976). More recently, improved land, resource and utilities management at both state and national levels require, up-to-date and complete cadastral maps (Williamson, 1996).

The present day cadastre is now digitised throughout the country with all jurisdictions having completed the digitisation process for all land parcels. A seamless cadastral database, called 'Cadastral Lite' integrated from each of the jurisdictional data sets and co-ordinated on the national reference datum, is available from the Public Sector Mapping Agency Ltd. The Australian cadastre covers approximately 10.2 million parcels including freehold, state owned land, strata titles and a very small number of native title parcels.

The complexity and data richness of the systems, coupled with centralised land registries in each jurisdiction, provided major impetus for computerisation of land titles. Titles automation has also been significantly driven from a 
business perspective to encourage better efficiency, reduction in registration times and to improve interoperability of handling variations in volumes of registration. Computerisation of all land data encourages integration of cadastral mapping to facilitate wider land management and environmental planning. Commonly one government agency is delegated the responsibility for maintaining an up-to-date cadastral map of all land parcels, while registration, land use management, and land taxation remain that of the custodians.

Australian digital cadastral maps today are typically a graphical representation of geometric components in electronic format, commonly known as digital cadastral databases (DCDBs) (Williamson and Hunter, 1996, Effenberg et al., 1999). The integrity of graphical DCDBs is supported by survey plans and field notes with legal measurements or graphical measurements in a digital parcel-based data set. In Victoria the cadastral and geodetic framework layers and topographic data, managed as separate road, elevation and hydrographic layers, are all integrated to produce the DCDB. Each jurisdiction has established different solutions, data models and processes for their digital cadastral data systems. Overall coordination of cadastral standards is being facilitated through ICSM (Intergovernmental Committee on Surveying and Mapping) with promotion of the Harmonised Data Model which aims to bring consistency to the fundamental data sets of each jurisdiction for better nationwide spatial data.

An example is given of the Victorian State DCDB and Figure 4 shows the output from this database via the Internet. A single parcel boundary has been highlighted, while the adjoining parcel is an example outlining strata or cluster type titles within a parcel.

The DCDB in the Sate of Victoria is known as Vicmap Digital. This is comprised historically of two separate databases with metropolitan Melbourne created from Melbourne Water (MW) and rural Victoria data created by the former Survey and Mapping Victoria. This was developed by hand digitised base maps in urban areas at 1:4,000 down to a scale of 1:500 (Williamson et al., 1998). Rural areas were similarly created by hand digitising parcel detail from parish, township, subdivision, and road survey plans and using overlays of orthophoto maps.

Compilation was mainly undertaken at 1:2,500 in densely populated areas and 1:25,000 in the remaining rural areas. These digital cadastral maps are under the control of Land Victoria in the Department of Sustainability and Environment. The initial data capture project for digitisation was completed in 1990.

The Victorian dataset series, as is common to most jurisdictions, contains data primarily representing land parcels and properties and is used extensively in Geographic Information Systems (GIS) by the public and private sectors. The content includes parcel polygons, proposed parcels (future development), parcel identifiers, municipal council reference numbers, road centre-lines, road easements and Crown and freehold land differentiation. Each of the data features is date stamped and uniquely identified.

Cadastral mapping is typically at scales of 1:2,000 - 4,000 in urban areas and 1:10,000 - 50,000 in rural areas.

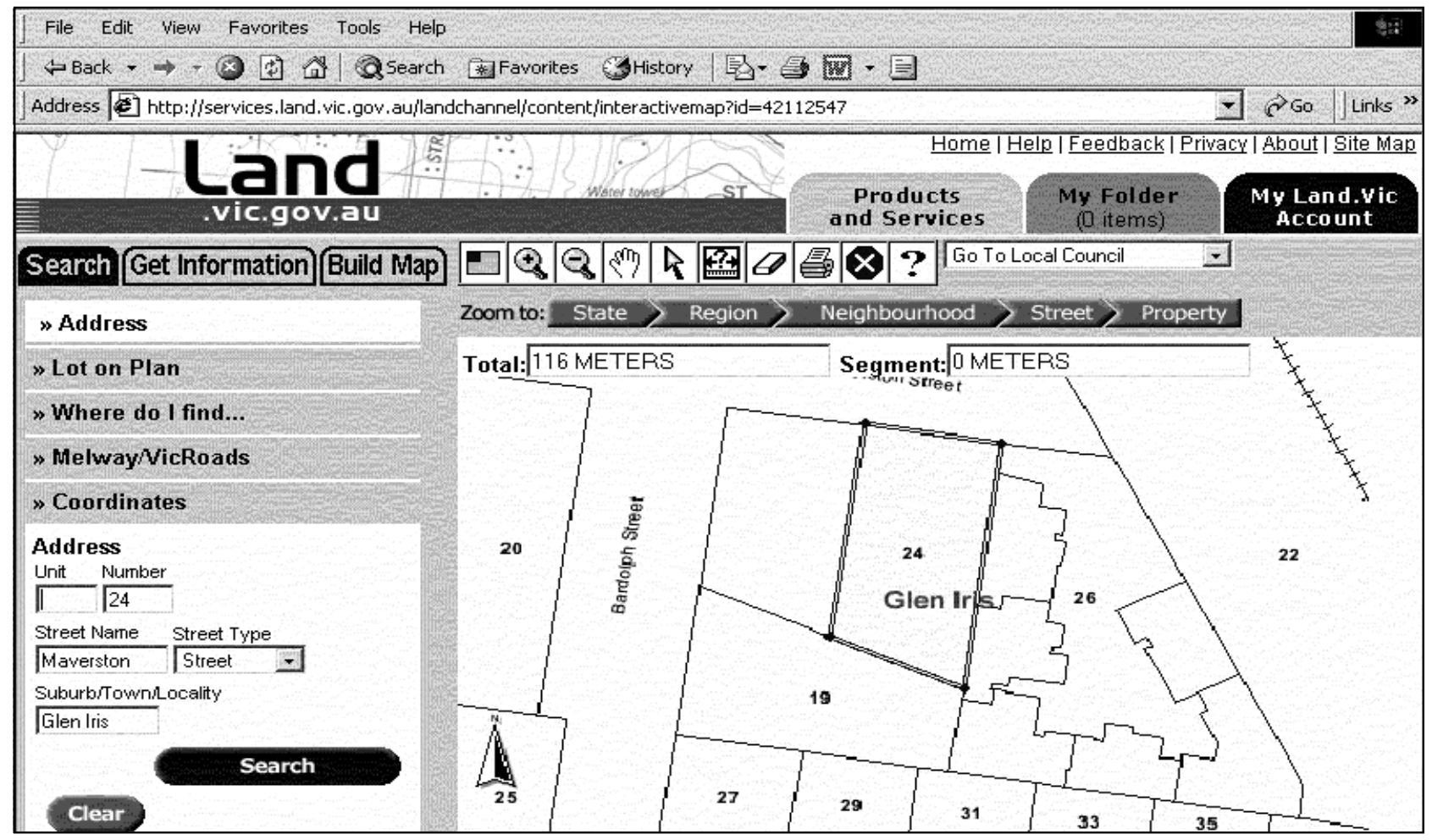

Figure 4 - Vicmap, Victorian DCDB (Courtesy of Land Victoria, accessed 20 th May, 2003) 
Cadastral maps in Australia represent boundaries to a graphical accuracy with the result that in urban areas coordinates of corners can be metres out of position and, in rural areas, tens of metres out of position. In some State systems accuracies of the scaled boundary coordinates are about $\pm 1 \mathrm{~mm}$ at map scale $( \pm 2.5 \mathrm{~m}$ at $1: 2,500)$

(Williamson et al., 1998). The accuracy of cadastral maps is continually being upgraded, especially in urban areas with accuracies significantly better than $\pm 1 \mathrm{~m}$ and often approaching $\pm 0.1 \mathrm{~m}$. The coordinates within the Australian Capital Territory, which is the basis of the cadastral map, approach survey accuracy. For more information on this coordinated cadastral system, see Williamson (1986).

Private land surveyors and many government agencies continually input cadastral detail validating and improving content. Both the computerised land register and DCDB in each state or territory are updated daily. Updates are available as whole file replacement or incremental files (changes only) with maintenance ongoing daily and incremental updates available fortnightly. Services to view and print cadastral information in most states are available via the Internet for a fee or available for purchasing through licensing agreements. Digital cadastral maps are available free of charge via the Internet with some limitations to information availability.

\section{THE ROLE OF THE CADASTRE IN SDI}

Increasingly business needs and technological developments demonstrate the value of spatial information in processes of economic, environmental and social decision-making (Williamson et al, 1998). In response to the demand for interaction of spatial data from both the public and private sectors, most states of Australia have established state land information units which oversee the collection and maintenance of spatial data as part of the jurisdiction's Spatial Data Infrastructure (SDI).

Responsibilities are usually in the same government department as surveying and mapping, which is pertinent to their successful development.

The key fundamental layer underpinning land administration within the SDI model at a State level is the parcel based cadastral layer. In most cases the cadastral layer provides the most distinctive, legally defined and unambiguous occupation and use of land on which to base a land information system. Data is linked to standard parcel identifiers in the cadastral layer thereby correlating information from each of the data sets through indexing to other parcel identifiers used by valuation, local government or utilities organisations, amongst others. Increasingly the focus in each state is on the development of core spatial data sets that provide the basic infrastructure to support the use of spatial information across a broad range of areas.

While these vary from state to state, most core spatial data sets organised in layers include:

- Cadastre

- Topographic

- Imagery
- Elevation

- Transport network

- Geodetic network

- Administrative boundaries

- Property addressing

- Geographic names

A generic model of the land information systems in each state is shown below in Figure 5. Even though this model was developed almost two decades ago, it is still relevant. It can be seen that the cadastral data component plays a central role in state land information systems.

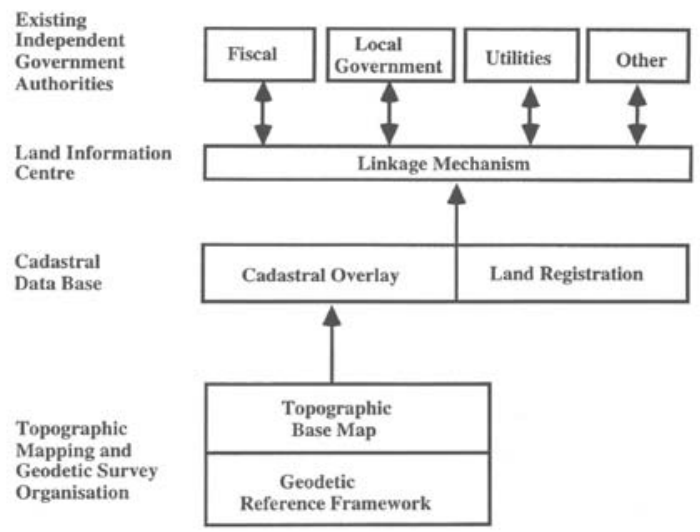

Figure 5- Land Information Systems (Williamson, 1985)

Recently the capacity to integrate and disseminate state and territorial spatial data was expanded to a nation-wide operation by PSMA Australia Ltd as part of an Australian Spatial Data Infrastructure (ASDI). Similar to the national digital cadastre, jurisdictions are increasingly contributing to the ASDI through networking databases. These are linked by common standards and protocols to guarantee consistency and compatibility and ensuring all agencies involved in spatial information management are able to communicate data and information directly with each other. As sharing, privacy and format issues are overcome, data sets are increasingly integrated within the framework.

At the state level, DCDB and components of the SDI increasingly support electronic conveyancing activities, online delivery of vendor statements certificates, Crown land, town, rural and urban planning and provide databases for activities in various authorities and public sector agencies, such as emergency response, homeland security and environmental risk assessment mapping.

\section{Current Issues}

Different issues affect each of the jurisdictions depending on the stage of spatial information development and particularly cadastral development. However issues of survey accuracy, seamless cadastres and online data activities are uniformly experienced.

The development of Australian cadastral surveying was 'piecemeal', created from isolated surveys and hence the 
move to adopt a fully coordinated cadastral survey system was a challenge now nearing completion. While all jurisdictions have achieved digital graphical cadastral maps, moves over time to upgrade these to survey accurate, as opposed to graphical accuracy, are evident. Upgrade will allow quality assurance of cadastral surveys to be undertaken quickly at low cost and will greatly facilitate updating the DCDB (Williamson, 1996). The integrity and accuracy of the cadastral dataset within the SDI will be significantly improved.

In addition, although the vision of a complete cadastre is accepted, achievement is proving difficult. The historical use of parallel systems of land registration for public and private lands continues to be problematic in some jurisdictions. The vision is for custodians to provide data that feeds into the one system. However, because data sources were separated for so many years, discrepancies between parcel boundaries and tenure arrangements arise. Adjudication and mapping solutions to overcome these problems are continually being sought and successful solutions are being found. Progress is expected to continue as long as historic institutional issues, corperatisation and privatisation issues are also resolved (Williamson, 1996).

Electronic, online conveyancing and registration services, such as digital lodgement of subdivision plans and transfer of title are posing technical, social and economic challenges. Concerns and risks are involved in issues of data compatibility, privacy, identity, fraud and pricing. Online land transfers aim to take away the necessity of 'over-the-counter' dealings, reducing time and cost. In the paper based systems, the copy title is the key to access to the registration process; this is not the case in the electronic environment. The digital systems will see reliance on a duplicate or copy of the title as an authority to change the register shift to electronic signatures. Conversion opportunities to a fully electronic environment are being investigated in some Australian jurisdictions (as well as in England and Canada), however there is some way to go before a wide spread and available electronic system gains the full support of nation-wide financial institutions.

Risk management and globalisation are affecting the way Australians manage their land administration systems. Professional indemnity insurance, covering clients for failure of standards and negligence, is now a standard requirement for surveyors, lawyers, conveyancers and other professionals. The guarantee or insurance function attached to land registration is narrowly based and generally a last resort option; three states require any other options for compensation to be exhausted before claims are granted. The international title insurance companies see these restrictions and non title risks involved in land transactions as creating opportunities for private title insurance. Their plan is to retail private title insurance policies through lenders. It remains to be seen whether private title insurance survives while the land registration system confidently delivers secure titles at relatively low cost for each transaction.

\section{Current Initiatives}

A federation of states in which each jurisdiction is responsible for its own development, produces a range of divergent approaches to key areas such as interoperability, jurisdictional responsibility, privacy, cost recovery, custodianship and access. This inhibits the development of wide scale spatial data sets. To address this issue, a Cooperative Research Centre for Spatial Information (CRCSI) was established between government, private and academic sectors to develop the concept of Virtual Australia (AUD\$80 million over 7 years). Its vision is to make spatial information available and useful to all persons in the nation at any time and at any place by uniting research and commercial innovation in spatial information. The focus is on growth of the private sector and commercialisation. The research program formulated for the CRC-SI is focussed upon future needs of the spatial information industry, as well as upon the infrastructures required to support the provision of these needs. The Centre plans five research programs, which will be highly integrated and linked by common threads ranging from application systems, including demonstrator projects, to quality and standards (http://spatialinfocrc.org/ index.html). The complimentary Centre for Spatial Data Infrastructures and Land Administration, Department of Geomatics, University of Melbourne (http://www.sli.unimelb.edu.au/research/SDI_research/) focuses maninly on public good research in the spatial information domain.

Technological initiatives are currently focussing on the dissemination of spatial information through SDI. The evolution of technology increasingly offers more avenues for enabling spatial information to be efficiently and effectively administered. Internet and Wireless Application Protocol (WAP) technologies are providing a lead to accessing the complex digital environment in SDI. Initiatives such as 'ePlan' (Land and Property Information, 2003) develop online plan lodgement and other electronic service deliverables to replace existing manual processes. While technical issues raised by these initiatives are being enthusiastically investigated, legal and institutional reform is also needed. Research projects and development studies are continually reassessing many user and provider issues associated with working in a new and innovative spatial environment.

\section{SURVEYING PROFESSION Education}

Surveying programs are offered at nine universities, in six jurisdictions of Australia, as a four year bachelor degree. Over the past decade traditional land surveying courses have taken on a much broader spectrum of education influenced by government and industry trends in spatial information activities. The field of surveying and spatial information systems of today require an understanding of measurement science from fundamental mathematics, science and legal education within an environment increasingly dependent on $21^{\text {st }}$ century concepts and technologies. Universities responded to this demand by upskilling the traditional surveying degree graduate with land 
use management, spatial planning, analysis and information systems management as well as by expanding land surveying and mapping to the marine and satellite positioning environments and moving more into the spatial dimensions of information technology.

The courses offered range in names from Bachelor of Surveying, Bachelor of Science (Surveying/Geomatics), Bachelor of Geomatic Engineering, Bachelor of Geomatics and Bachelor of GeoInformatics and Surveying. The degrees offered, although covering broader spatial information topic areas, remain the prerequisite for entering the professional field as a registered or licensed surveyor. Current student numbers at the undergraduate level around the Australian universities are approximately 1500 with about 350 graduate students involved in surveying or survey related research areas, ranging from graduate diplomas to doctorates. About $20 \%$ of students studying surveying at an undergraduate level in Australia are women.

An example program is the Geomatic Engineering Bachelor degree at The University of Melbourne, Australia's first surveying course (Certificate of Surveying in 1861). The Department of Geomatics, within the Faculty of Engineering offers a 4 year straight honours degree or combined discipline degree of 5-6 years with Science, Arts, Information Systems, Planning and Design and Law. There are approximately 245 undergraduates. The department also has a strong research focus with 40 50 postgraduates undertaking either a Graduate Diploma/Certificate, Masters or Doctor of Philosophy in Geomatics or specializing in Geographic Information Systems (GIS). Extensive research and development programs are undertaken in the areas of land and geographic information systems, cadastral systems, land tenure, measurement science and digital photogrammetry, most of which are undertaken in partnership with industry or government. Services, centres and major projects within the department continually nurture these research areas. See www.geom.unimelb.edu.au/centres.html for more information.

\section{Registration}

Under the Torrens System of title registration, the state guarantees entries in folios of the land register. While relationships between land on the ground and information in surveys and maps used in registration processes are not guaranteed, the integrity of the system depends on consistent application of the highest standards of surveying to ensure land is reliably identified. Surveyors therefore act on behalf of the client and as 'an agent of the state' to ensure the integrity of the land tenure system (Ristevski and Williamson, 2001). Surveyors Acts and Regulations established licensing and registration of cadastral surveyors to ensure the maintenance of standards, and to ensure surveyors acting on behalf of the state are fit and proper and equipped with the appropriate knowledge and skills to perform cadastral surveys. Under the Reciprocating Surveyors' Board of Australia and New Zealand, persons registered by a Board in any state or New
Zealand, can apply for registration in any other of these jurisdictions under a reciprocity agreement.

A person applying for registration must be issued with a certificate of competency in surveying or cadastral surveying specified by the Act in the relevant jurisdiction. This typically requires 18 to 24 months under a training agreement with a registered/licensed surveyor. In addition states require persons to pass further professional examinations and practical exercises to the satisfaction of the respective board of surveyors. A prerequisite for entry into a training agreement is a degree or diploma approved by the board, such as those degrees mentioned earlier, either within the state of registration or a reciprocating state.

Modern expansion of the use of spatial information is evidently demonstrated by career paths of surveyors. Only about $20 \%$ of graduates now pursue registration to undertake cadastral surveys, with the rest working in other areas of surveying or in allied industries or professions. A graduate surveyor does not have to be registered to undertake surveys other than cadastral surveys, although registration as a surveyor is seen to be acknowledgment of a high professional standard.

\section{Institutional Organisations and Arrangements}

The regulation of surveyors was recognised as early as 1837 with the licensing of government land surveyors (Ristevski and Williamson, 2001). Only 7 years later the private sector entered the profession playing a minor role. By the 1880 's a representative body for professional surveyors primarily interested in cadastral issues was institutionalised and the first Institute of Surveyors division originated. Over the decades a representative body was formed in all states and territories, servicing 3,800 existing members, with a national representation by the Institute of Surveyors Australia.

Gradually over the past 100 years the roles of surveyors in government and of the Surveyor General have gradually declined. This was accelerated over recent decades when government downsizing and restructuring forced expansion in the private sector to undertake most cadastral, engineering and other surveys. Some states dropped the term "surveyor general", while in others, the title still retains significant authority and stresses the importance and standards of surveying to ensure "the correctness and accuracy of the location of property, boundaries, buildings and all infrastructure" (Surveyors Board of Victoria, 2002). As society relies more on spatial information, the need for surveying and mapping organisations to uphold the standards of the profession grows more crucial. An institution representing professionals in the cross disciplinary spatial sciences industry was established for Australia in 2003 in response to rapid evolution of the spatial industry. The Spatial Sciences Institute (SSI) is dedicated to improving professional development among spatial science industry professionals through workshops, international participation and contribution to standards, committees etc (Spatial Sciences Institute 2003). The SSI is strengthened by incorporating well established 
institutions such as the Institution of Surveyors Australia (ISA), the Institution of Engineering and Mining Surveyors, Australia (IEMSA), the Mapping Sciences Institute, Australia (MSIA), the Australasian Urban and Regional Information Systems Association (AURISA) and the Remote Sensing and Photogrammetry Association of Australasia (RSPAA).

At a national level, surveying and mapping coordination and cooperation is provided by the Inter-governmental Committee on Surveying and Mapping (ICSM) represented by Australia's Commonwealth, State, Territory and Defence surveying and mapping agencies. The Reciprocating Surveyors' Boards of Australia and New Zealand control cadastral surveys across jurisdictions and the Australia New Zealand Land Information Council (ANZLIC), established in 1986, coordinates land and geographic information. The Australian Spatial Data Infrastructure initiative arose from this Council, which involves the responsibility of leading the development of spatial information management. Additional government agencies at a Commonwealth level assist with policy and spatial data management (Geosciences Australia) and at the technical level through the Public Sector Mapping Agency Ltd.

The private sector survey industry interests are promoted and represented by the Australian Spatial Information Business Association (ASIBA). The recently formed Australian Spatial Industry Education and Research Association (ASIERA) is anticipated to perform the same peak body role for the academic and research sector that ASIBA performs for the private sector.

\section{CONCLUSION}

Cadastral systems found in the Australian states were developed to serve the specific needs of a vast developing nation over the last two hundred years. Australian cadastral systems are unique and, like most systems cannot be readily transferred to other countries. However many aspects of the Australian system, such as the world renowned Torrens system of title registration, have been successfully adopted by many countries to varying degrees.

Due to the inherent wealth of Australia, relatively expensive and complex cadastral systems were allowed to evolve in the individual jurisdictions. These systems work well and underpin a secure land transfer system supporting an active land market. Furthermore, although Australian cadastral systems were not designed as part of a wider land administration system, they now form its foundation and are becoming increasingly important within the wider spatial information environment.

The requirements of Australian cadastral systems demand well trained and educated professionals. Cadastral surveying services are almost solely provided by the private sector; however the administrative and maintenance support of government upholds the standard of core spatial data sets that underpin the use of spatial information. There is no doubt that over the next decade or so cadastral systems will become simpler as coordinates are universally used and as digital cadastral databases become fully established and their accuracy upgraded. Australian surveyors, conveyancers and legal professionals have a very good reputation for finding pragmatic solutions to difficult problems. However many of the limitations to cadastral reform are institutional reflecting the strong historical foundations which shaped the cadastral system. Building partnerships and intergovernmental agreements are essential to moving forward while maintaining high standards and using advanced technologies.

With the strength of the land market, Australia can afford a relatively expensive system whereas many other countries cannot and have to look at more cost effective approaches to providing the infrastructure on which to base an efficient and effective land market and to serve broader land policies.

The importance of surveying as a backbone to economic development, environmental management and community planning should not be underestimated. The rapid change experienced by surveying professionals is threatening to some, but most enjoy participating in a very exciting period in which technology expands horizons and opens new areas.

\section{ACKNOWLEDGMENT and QUALIFICATION}

We acknowledge the suggestions and critical comment relating to this paper from Professor Stig Enemark, University of Aalborg, Denmark. The authors are members of the Centre for Spatial Data infrastructures and Land Administration in the Department of Geomatics at the University of Melbourne and acknowledge other members of the group for their assistance and contributions. We are grateful for the input from Associate Professor Gary Hunter, also from the Department of Geomatics, and Mr Peter Ramm and Helena Kallista of the Land Information Group, Land Victoria, Department of Sustainability and Environment. The views and information expressed in this paper are those of the authors, and do not necessarily reflect the views of the individual jurisdictions. Readers should acknowledge that this paper is an overview of Australian cadastral systems and as a result does not identify all the differences in law, regulation and practice in the different jurisdictions. If readers wish detailed information on the individual jurisdictions, please refer to their respective websites and to the overarching surveying, mapping and spatial information bodies, PSMA Australia Ltd, ICSM and ANZLIC.

$\begin{array}{ll}\text { Australian Capital Territory } \\ \text { New South Wales } & \text { http://www.palm.act.gov.au/actlic/ } \\ \text { Northern Territory } & \underline{\mathrm{http}: / / \text { www.lpi.nsw.gov.au }} \\ \text { Queensland } & \underline{\mathrm{http}: / / \text { www.nrm.qld.gov.au }} \\ \text { South Australia } & \text { http://www.landservices.sa.gov.au } \\ \text { Tasmania } & \underline{\mathrm{http}: / / \text { www.dpiwe.tas.gov.au }} \\ \text { Victoria } & \underline{\mathrm{http} / / \text { www.land.vic.gov.au }}\end{array}$

Australian Capital Territory

New South Wales http://www.lpi.nsw.gov.au

Northern Territory http://www.lpe.nt.gov.au

http://www.nrm.qld.gov.au

Tasmania $\quad$ http://www.dpiwe.tas.gov.au

htp.//www.land.vic.gov.au 
Western Australia http://www.dola.wa.gov.au PSMA Australia Ltd http://www.psma.com.au

ICSM http://www.icsm.gov.au

ANZLIC $\quad$ http://www.anzlic.org.au

\section{REFERENCES}

Barrie, J. K. (1976) The Surveying Profession in Australia: A Personal Interpretation of its Historical Development, Current and Future Trends. The Australian Surveyor, 28 (1), pp. 6-56.

Chappel, K. L. (1996) Surveying for Land Settlement in Victoria 1836-1960, Office of the Surveyor General, Melbourne, Vic.

Dale, P. F. (1976) Cadastral Surveys within the Commonwealth, Her Majesty's Stationary Office, London.

Effenberg, W. W., Williamson, I. P. and Enemark, S. (1999) Framework for discussion of digital spatial data flow within cadastral systems. The Australian Surveyor, 44 (1), pp. 35-43.

Hallman, F. M. (1973) Legal Aspects of Boundary Surveying as Apply in New South Wales, Sydney: Institution of Surveyors, Australia, New South Wales Division.

Land and Property Information (2003) Conveyancing, Dealings and Plan Information, Department of Information Technology and Management, New South Wales, http://www.lpi.nsw.gov.au/eplan.html

Ogleby, C. (1993) Terra Nullius, The High Court and Surveyors. The Australian Surveyor, 38 (3), pp. 171-189.

Park, M. and Williamson, I. P. (1999) Australian Cadastres: the Role of Adverse Possession of Part Parcels. The Australian Surveyor, 4 (2), pp. 151-158.

Prescott, V. (1994) Mapping Mabo. In XX Congress of the International Federation of Surveyors, 5-12 March, pp. 326-336.

Ristevski, J. A. and Williamson, I. P. (2001) The Reform of Statutory Regulations Relating to the Surveying Profession. The Australian Surveyor, 46 (1), pp. 42-53.

Spatial Sciences Institute (2003) Media Release, Spatial Sciences Institute, Canberra, Australia - April 4, 2003.

Survey Practice Handbook - Victoria. Board of Surveyors, Victoria. (1994) now available online, http://www.land. vic.gov.au/web/root/domino/cm da/lcnlc2.nsf/frameset/ surveying

Surveyors Board of Victoria (2002) http://www.land.vic. gov.au/web/root/domino/cm da/lcnlc2.nsf/frameset/ surveying, accessed $20^{\text {th }}$ May, 2003.

Williamson, I. P. (1984) The Development of the Cadastral Survey System in New South Wales. The Australian Surveyor, 32 (1), pp. 2-19.
Williamson, I. P. (1985) Cadastres and Land Information Systems in Common Law Jurisdictions, Part 1. The Survey Review, 28 (217), pp. 114-129.

Williamson, I. P. (1992) Cadastral Reform and the Politics of Land and Geographic Information Systems. In International Conference on Cadastral Reform '92, 29 June - 1 July, Melbourne, Australia.

Williamson, I. P. (1996) Establishing Coordinated Cadastres - Australian Experience. In International Conference on Cadastral Reform, 16-17 July, Korea, pp. 8.

Williamson, I. P., Chan, T. O. and Effenberg, W. W. (1998) Development of Spatial Data Infrastructures Lessons Learned from the Australian Digital Cadastral Databases. Geomatica, 52 (2), pp. 177-187.

Williamson, I. P. and Enemark, S. (1996) Understanding Cadastral Maps. The Australian Surveyor, 41 (1), pp. 3852.

Williamson, I. P. and Hunter, G. J. (1996) In A scoping study for the Office of Surveyor General and Office of Geographic Data CoordinationDepartment of Treasury and Finance, Government of Victoria, Melbourne, pp. 42.

Williamson, I.P. and Rainbird, B.C. (1986) The Australian Capital Territory Cadastral Survey and Mapping System. The Australian Surveyor, 33 (4), pp. 306-326. 


\section{University Library}

\section{- M M N E R VA A gateway to Melbourne's research publications}

Minerva Access is the Institutional Repository of The University of Melbourne

Author/s:

Dalrymple, Kate;Williamson, Ian P.;WALLACE, JUDE

Title:

Cadastral systems within Australia

Date:

2003

Citation:

Dalrymple, K., Williamson, I. P., \& Wallace, J. (2003). Cadastral systems within Australia. The Australian Surveyor, 48(1), 37-49.

Publication Status:

Published

Persistent Link:

http://hdl.handle.net/11343/33969 